\title{
Before Orbis Pictus: Some Notes on Comenius' Latin Textbooks
}

\author{
Irina L. Guseva - Vladimir V. Rybakov
}

\begin{abstract}
The authors of the current paper study Latin textbooks written by J. A. Comenius before his Orbis pictus (1658). In attempt to explain book title Janua linguarum reserata they draw reader's attention both to the real history of its composition and to its possible symbolic interpretation. Close attention is paid to Vestibulum, the first textbook of the series Vestibulum - Janua - Atrium, intended for children of six-seven years old. It is argued, that it was a figure of king Solomon and his personified Wisdom that stood behind the general layout of Vestibulum determining its title, its first chapter and more (particularly, a paragraph on numerals is analyzed in details). The authors make a try to find allusions to New Testament in Janua and Vestibulum and to trace indirect influence of some pericopes from Scripture on Comenius' textbooks. Unconsciously, the philosopher of the XVIIth century was bound to biblical tradition coining phrases and verbal images that had implicitly inherited patterns from the Holy Bible.
\end{abstract}

\section{Keywords}

John Amos Comenius; textbooks; Vestibulum - Janua - Atrium; the Bible; king Solomon; wisdom

This article is a result of the research project Some pages of John Amos Comenius' scientific legacy out of reach in Russia: research strategies, texts, investigation which has been supported by the Russian Foundation for Basic Research (Department for Humanities and Social Sciences), project number: 17-06-00075. Some results presented in this paper were partly and in a shortened form published in Russian, in V. Rybakov's article, included into a journal Seeking in Psychology and Pedagogy (2017, issue 1). We would like to thank Ulrich Schäfer for help and valuable hints concerning various editions of Vestibulum and their circulation in Europe. 
If our contemporary, being asked about Comenius, recalls, first of all, The Great Didactic (Didactica Magna) and The Visible World in Pictures (Orbis pictus), people of the epoch of Comenius knew him mostly as a compiler of a Latin manual - Janua linguarum reserata. ${ }^{1}$ That manual immediately put its author on the map and was issued numerously - both in its basic form and in modified versions, above all multilingual ones (see notes 10, 24). The Czech scholar introduced an ingenious idea of a structure of a language manual. Soon, a number of imitations appeared, there was a whole bunch of epigones; and the author was only happy to observe it, in the tune of his time. As J. Červenka notes, as soon as the manual was printed in the Polish town of Leszno in March 1631, news on it were spread through all the enlightened countries of Europe (Červenka 1959: p. V).

The title Janua linguarum was taken from one Irish Jesuit, William Bathe, who issued a book of the same name in $1611 .^{2}$ In the foreword to his own edition, however, Comenius noted sarcastically: it was so difficult to learn Latin with the book by Bathe (which he personally had not read or seen in original version, as we know, obtaining only a copy with translations into German, French, Italian, Spanish and English, issued by Isaak Habrecht in 1629), that it should be titled not Janua (entrance), but Posticum (back door), and it suited more for checking how much had semi-initiates caught on tops, than for correct, consistent, gradual learning of the youths. ${ }^{3}$ Noteworthy, the title of the manual by Comenius was a citation and a kind of polemics with Bathe. The formula Janua linguarum (a door to languages) was completed with a participle reserata (unlocked) - it was an obvious hint to the fact that the previous 'door' (the manual by the Irish Jesuit) was locked and didn't give a chance to learn anything from it (compare below in the current article another interpretation of the term reserata in the biblical context).

Popularity of Janua didn't prevent Comenius to be not really satisfied with his work. ${ }^{4}$ He treated the book as too complicated for the beginners, because it put boys 'into a thick forest of objects and words' (in tantam rerum et verborum sylvam) at once; so, he had an intention to make an additional, simpler Latin manual for children of six-seven years old. Those plans Comenius explained clearly in the foreword to Vestibulum (Antechamber), as he titled his elementary manual. ${ }^{5}$ The first edition of Vestibulum, obviously,

1 On the immense popularity of Janua in France in the XVIIth century see the observations of a contemporary: Nicole (1671: p. 49).

2 General introduction into the problem: Steiner (2007: p. 177); Mištinová (2000). For further reading on Bathe and his mixed method of learning languages see: Corcoran (1872); Ó Mathúna (1986).

3 Haec autem Patrum Hibernorum Ianua tyronibus in Latinitatem aliunde introducendis aut parum aut nihil confert. Triplici id evincitur ratione. Primò etenim nonnulla vocum pars, quas quotidianus requirit usus, hic desideratur, è contra insolentia multa, tyronum captum et usum excedentia, depromuntur. Quam ob causam recte M. Joh. Rhenius judicavit Iesuiticam hanc Ianuam non tam ad instituendos linguarum tyrones, quàm ad explorandos aliquousque progressorum, imprimis autem sciolorum, in Latina lingua profectus adhiberi posse. Isthac verò ratione non Ianuae, sed Postici obtineat nomen (Červenka 1959: pp. 4-5).

4 Wider (especially international) context of different conceptions and various ways of teaching languages in Comenius' times is presented by J. Caravolas: Caravolas (1993). Almost all teachers of languages were not completely satisfied by the methods they had used. Comenius was not an exception.

5 Contestatus eram in Januae illius meae praefatione, eam Latinitatis tironibus parari; atqve sic etiam publice excepta est. Verumenimvero metuendum existimo, ne in tantam rerum et verborum sylvam tirones ex improviso immitti, nimium sit. Tutius fuerit in vestibulo detineri, generaliaqve totius structurae (id est summos rerum et verborum 
was issued in $1632,{ }^{6}$ but, as well as the second one of 1633 , it has not been preserved till nowadays (DJAK, 15/I, pp. 509-510). Thus, compilers of the Complete Works by John Amos Comenius, who prepared the first and the only so far critical edition of the $A n$ techamber (by Stanislav Sousedík), had to restore the initial author's idea on the base of three editions made during his lifetime, taking the text from the first part of the famous Amsterdam collection of his pedagogic works as a principal source. ${ }^{7}$ Two other sources for that restoration included the Leipzig edition of $1636^{8}$ and the London one of $1641 .{ }^{9}$ Afterwards, Vestibulum and its variations have been used everywhere in Europe for about two centuries. ${ }^{10}$ Comenius himself issued a modified version of his Antechamber in 1652 for a school in the Hungarian town of Sárospatak, where he had been working for a long time. (Let us note that he made changes to his Janua three times as well, and it can be clearly seen in a synoptic edition by J. Červenka, see bibliography; synoptic edition of the Vestibulum still remains a desideratum).

The book is interesting in many aspects; it would be difficult to describe it in a short and univocal way. In appliance with the characteristic made by Comenius himself (e.g. in his epistles), it appears to be something not ripe, not accomplished - wine which hasn't fermented. The author had considered to compile it from simple dialogues - like those spontaneous talks of schoolchildren, but then he decided to make its structure closer to Janua, thus creating series of three books, where similar chapters are repeated thrice and developed with additional material on each new step (DJAK, 15/I, 307) (see further in the current paper).

cardines) prius monstrari, qvam ad particularia lustranda intromittantur. Hoc consilio praesens opusculum conscriptum est, ut primis tironibus declinationes et conjugationes (saltem analogas) exercendi prima sit materia, et ad Januam ipsam accessus... Faxit autem Deus, ne a Coeli Januâ, Christo, aberremus, qvicunqve Coelo natos Dei filiolos erudiendos suscipimus. Qvod potissimum agite, ô scholarum moderatores, per vestram et vobis commissorum salutem obtestor (DJAK, 15/I, pp. 307-309).

6 In his Novissima lingvarum methodus (written probably between 1644 and 1648) Comenius says: Vix autem illud adornaram, cùm animadvertere coepi tironibus primis ad Januam illam difficilem fore aditum necessarióque illi praestruendum esse Vestibulum: praestructum itaque est annô sequenti, 1632 (VIII, 23, DJAK, 15/II, p. 164). And further (XIV, 4): In prima Vestibuli editione (anno 1632) selegeramus totius lingvae vocabula faciliora... (DJAK, 15/II, p. 241). Here we have additional arguments for the date of 1632.

7 J. A. Comenii Opera Didactica Omnia. Variis hucusque occasionibus scripta, diversisque locis edita: nunc autem non tantum in unum, ut simul sint, collecta, sed E $\mathcal{F}^{2}$ ultimo conatu in Systema unum mechanice constructum, redacta. Amsterdami, Impensis D. Laurentii de Geer, excuderunt Christophorus Cunradus, Ẽ Gabriel à Roy. Anno M. DC. LVII

8 Januae Lingvarum Reseratae Aureae Vestibulum, Quo primus ad Latinam aditus Tirunculis paratur: Cum versione interlineari Germanica. Editum à Johan-Amoso Comenio. Nunc verò ipsius Autoris Consensu Revisum multisque in locis auctum. Cum Privilegiô Sac. Caes. Majest. Et Sereniss. Elect. Saxon. Lipsiae, Sumptibus Gotofredi Grosii Bibliopolae. Per Johannem Albertum Mintzelium Typis excusum, Anno M. DC. XXXVI.

9 Janua linguarum Reserata: ... unà cum Januae Latinitatis Vestibulo. Authore Cl. Viro J. A. Comenio. The Entry Door of Languages Unlocked ... together with a Portall to the Janua. Formerly translated by Th. Horn: now reviewed and enlarged both in the Latin and English, By Joh. Robotham. The fifth Edition. London, Printed by R. Young, and are sold by T. Slater, at the Swan in Duck-Lane, 1641. On early version of Comenius' textbook, printed in Leszno by Daniel Vetter, see Steiner (1987).

10 There existed editions in Greek (Ancient), German, Hungarian, Czech, Polish, Dutch, English, French, Italian, Danish, Swedish and, possibly, even Russian (by famous Johann Ernst Glück). See Čuma (1961). 
Noteworthy, the Antechamber was filled not only with didactic and scholastic spirit (natural for a school manual of the seventeenth century), but also with Christian mysticism seen through seeming simplicity and clearness typical for elementary course books. Reading Vestibulum, our contemporary soon finds out that such concepts as 'wisdom' and 'science' - nowadays quite different in their meanings - were almost identical in the epoch of Comenius. After all, the Holy Scripture was a source of wisdom and, consequently, a source of science. Some books of the Bible happened to be more actual than others. There was a well known concept of 'didactic books', i.e. the Book of Job, the Psalter, the Book of Proverbs, Ecclesiastes, the Song of Songs, the Book of Wisdom of Solomon, and the Wisdom of Sirach. Those books were of special importance for the pedagogic discourse of the seventeenth century - both for Catholics and Protestants (to whom Comenius belonged).

In the ninth chapter of the Book of Proverbs, wisdom is personified and acts as a human being: 'Wisdom has built her house' (Sapientia aedificavit sibi domum, Proverbs 9:1). That short aphoristic formula, obviously, served as a source of the title of the famous trilogy by Comenius, who 'broadened' the Bathe's idea to the both 'sides'. The first two parts of the trilogy included the abovementioned Antechamber (Vestibulum) and Door/ Entrance (Janua), and the third part was published in 1652 only, although planned earlier - it was the so called Hall (Atrium, its full title is Atrium rerum et linguarum ornamenta exhibens). ${ }^{11}$ A philosopher and a teacher, Comenius as if built a metaphor for the process of learning, i.e. acquiring science and wisdom - a progress from the antechamber of a house (vestibulum) to its main chamber, a hall (atrium), from which a student could see entrances to various chambers of specific sciences. That house was a house of Wisdom, mentioned by Solomon, the greatest sage of the Old Testament and a symbol of wisdom as such.

According to the Vulgate, having built a house, Wisdom calls those who are 'simple' parvuli, i.e. little children (Si quis est parvulus, veniat ad me, Proverbs 9:4). The Antechamber by Comenius was compiled exactly for them - not without reason he opened it with the words Venite pueri ['Come, little ones (= children)'], ${ }^{12}$ repeating words by Wisdom from the Book of Proverbs: 'Come, eat my bread and drink the wine I have mixed. Leave your simple ways and you will live; walk in the way of insight' (Venite, comedite panem meum, et bibite vinum quod miscui vobis. Relinquite infantiam, et vivite, et ambulate per vias prudentiae, Proverbs 9:5-6). Bread and wine of this citation could serve as a hint to the Eucharist and gave some mystic hue to the process of learning and bringing up, making the process of schooling into a sacred rite. The call 'come' (venite) was used in the

11 Eruditionis scholasticae pars III. Atrium, rerum et linguarum ornamenta exhibens. In usum scholae Patakinae editum et in chalcographia celsiss. prin. Exscriptum. Sárospatak, 1652.

12 In the Leipzig edition (as note 8), there is another text: Salvete pueri, venite tirunculi ('Welcome, little ones, come here, pupils'), see: DJAK, 15/I, p. 422. Such correction seems a way of radical changing all the Comenius' idea and plan. Puer is a singular of liberi that is pueri=liberi, pusus/-illus has the same stem meaning 'small', see further: Walde \& Hofmann (1954: pp. 382, 392-393). Pusillus and parvulus are often intermixed being paronyms and having close semantics. So we can suppose a semi-etymological and semiparonymic chain puer-pusillus-parvulus. In simple words, those three lexemes have similar pronunciation and similar meaning. 
Catholic Sacred Service, well known to Comenius (compare such famous chants as Venite adoremus or Venite exsultemus, and a rare chant Venite pusilli simul et magni; even more examples could be found in Analecta hymnica); so, under some assumption, we could interpret it as a call to a sacred service.

So, three consequent Latin manuals for children - Vestibulum, Janua, and Atrium were three parts of the 'house of Wisdom', precisely speaking, three parts of the human way through that house. On the base of the allegorical interpretation of the house, given by the initial source, the author made titles of the manuals, as well as the very idea of their consequent usage, as a gradual progress to the centre of the house ${ }^{13}$. The most explicit way of presentation of that idea could be found in The Great Didactic by Comenius (XXII, 18-24). The first word of the first section of the Antechamber ${ }^{14}$ was the call venite (come) taken from the fifth verse of the ninth chapter of the Book of Proverbs. And the third sentence of the same section included the word 'Wisdom' (with the capital W) as an additional reference to Wisdom of the Proverbs: comprehendite... Sapientiae semina ('comprehend seeds of Wisdom'). ${ }^{15}$ A teacher calls for children to come to his school in the same way, as the personified Wisdom calls for parvuli (simple and little) to come to her house for a dinner.

The same system of religious concepts is developed in the text of the manual even further; it is most obvious in the section 'Numerals' of the third chapter of the Antechamber, where the development is manifested not hidden, but openly. Latin numerals from one to ten (but not only they) are enumerated. To remember the word 'one', it is recommended to learn a phrase: Unus est codex Bibliorum. It is not easy to translate it literally, but the main sense is the following: 'the Bible is unique', or 'the codex of the books of the Holy Scripture is the one and only'. So, it was not the main object that was taken for remembering the idea of 'one' - not 'there is one God', as we could suppose, but 'there is one Bible'. We might offer several explanations of such a choice.

The first one is the following. The number 'one' is to be learnt in a line with 'two' associated with two Testaments - Old and New, so we have an antinomy: 'there is one Bible, and two Testaments'. Similar antinomies could be found in the first chapter of the Antechamber; for instance: 'Angel is immortal, human being is mortal' (Angelus immortalis,

13 As far as we know, Comenius thought the allegory to be developed further; the next two books were to be titled Palatium (palace, apparently another name of Atrium) and Thesaurus (treasury): 'Nos tamen inde excitati et re penitiùs expensâ, animadvertimus totum lingvarum studium commodissimè in quattuor disterminari gradus: balbutiem, loquelam, facundiam et denique plenam eloquentiam; destinandaque hauriendis illis esse instrumenta et appellanda Vestibulum, Januam, Palatium, Thesauros Latinitatis. Quod anno 1637 datâ in lucem Dissertatione didacticâ etc. eruditorum insusurravimus auribus. Placuit permultis consilium: sed quod manum nemine admovente nobisque occupatis alibi exsequutioni datum non fuit' (Novissima lingvarum methodus, VIII, 24, DJAK, 15/II, p. 164). As we mentioned earlier in the article, the plan was initiated with an imitation of the book by William Bathe (for references see note 2).

14 This section was titled differently in different publications: introitus (i.e. 'approach', 'the first step'), praeloquium ('introduction'), and invitatio ('invitation'). The third variant is kept also in Orbis pictus, based on Vestibulum. In the critical edition of the work editors accepted the reading praeloquium (DJAK, 15/I, p. 311).

15 Editors of the Complete Works by Comenius preferred not to use capital letters, if they were not in the beginning of sentences, and it changed the text in comparison to that one of the publications of the seventeenth century; many accents and connotations were lost, as a result. 
Homo mortalis). From the other hand, 'three' is for the Holy Trinity, and 'four' - for the Evangelists (not for the four Gospels); and the logics of the first two points (about books) is not developed directly. Another possible explanation is that children of six-seven years old were considered too young for the concept 'there is only one God' and the Holy Trinity at once to be taught at school, because the dogma of the Trinity was difficult even for many adults.

Besides, we may suppose a certain hidden meaning of such comparison inset by the author - intentionally or not. We dare say, the aim of the comparison of the words 'one' and 'the Bible' was designed to stress a unique importance of that book, which was considered as a unique source of the truth. ${ }^{16}$ At that, the statement would be false if it is applied to any one book of the Bible, because the very sense is in the "collection of all its books' (the literal meaning of $\beta \iota \beta \lambda i ́ \alpha$ in Greek, as we know, is 'books'). Thus, we may offer another explanation: the word 'one' means not only single but also unique and inseparable. ${ }^{17}$ In this case, the phrase Unus est codex Bibliorum would mean: 'the volume of biblical books put in a certain order is unified', i.e. it is a whole text, not a collection of occasional parts. That theological concept was rather complicated, thus, it influenced latently on the author and was 'translated' to boys (pueri) through the manual, but we cannot judge was it intentionally or not.

In the Amsterdam edition (see note 7), the paragraph on the numerals was divided into 16 sections. The first section is an introduction; the sections from the second to eleventh are about the numerals from one to ten, then there are the numerals 11, 12, 30, 100 , and 1000 , so, there are five more sections. The general title is Numeralia (numerals). The last section declares: 'Satan is inventor of a thousand of criminal plans' (Satanas est mille fraudum artifex). Now, let us imagine that the second section is 'there is one God', there would be a blasphemous composition: the chapter is opened with God and closed with Satan, the more so because the numerals are put in the increasing order, from the smallest to the biggest one.

There are fifteen sections (excluding introduction), and Christian concepts were used in five ones. Three of fifteen sections mentioned periods of time which should be learnt also at the initial level of education. Among these periods, there were 'eight' days of the week (because Sunday was added to two weeks at once - to the finished and beginning ones), ${ }^{18}$ 'thirty' days of a month, and 'hundred' years of a century. Two most interesting sections are 'five' and 'nine'. The author meant 'five' senses (Qvinque sensus), and, obviously, 'five gates of learning' (we might suppose the influence of sensationalism) or 'five

16 Let us make a casual remark, that Protestants, including the Bohemian brethren, among whom Comenius lived and was the last bishop, rejected the sacred tradition, so, the Holy Script was the only source of religious knowledge for them. The same logical chain is present in the philosophical works by Comenius (e.g. Physicae synopsis), especially in the third period of his work (1628-1641). See in general: Čapková (1987: pp. 43-46).

17 Noteworthy, the idea of unity could be expressed with the antinomy 'God is the only one (unique), and Persons are three (though God is one)', but, as we have said before, the idea of Trinity, probably, was perceived as too complicated for the primary school.

18 In this case, there is an indirect connection with religious theme, because 'octave' (the eighth day) after many festivals was celebrated in a special way. 
objects of bringing up' (we might suppose the influence of medieval conceptions about human nature).

The most enigmatic section is 'nine', identified as 'three times three'. We can hardly see here a desire to present a concept of 'a square of natural number' to children, or to give them an idea of the first numeral-adverb (ter) in their life; it is clear that the section makes a hint to some philosophical or religious matters. In the numerology of the seventeenth century, the number 'three' corresponded to the Holy Trinity, three sources of knowledge, three parts of the human soul, and so on. So, that number multiplied on itself was to give another symbolical number, i.e. nine. Perhaps, for Catholics that 'three times three' meant the hierarchy of angels' ranks, in a modified version of PseudoDionysius, which included three levels - three ranks in each one. But the angels' ranks were apparently eliminated from the curricula of Protestant schools, so, there remained just 'three times three' in the manual by Comenius.

The first word of each of fifteen sections is a numeral, so, they can be read one after another, in a column; but in two cases this rule is broken - in the section with Satan and a thousand of his frauds, and in the section on nine: Ter tria sunt novem ('Three times three is nine'). In the first case, the numeral is in the middle of the phrase; in the second case, it is in the end of the phrase. It puts two sections in a special position inside the general scheme.

Comenius did not consider Vestibulum as a separate textbook; it was a kind of propaedeutics, a short introduction to Janua, its shortened and simplified version, or even an 'appendix' (see the earlier cited introduction to the Antechamber, DJAK, 15/I, pp. 307-309). In the trilogy Vestibulum - Janua - Atrium, the first element seemed the less important for the author (in its content, not in the didactic sense). In general, a pupil who passed Vestibulum only, and has not learnt yet, had a chance to repeat the same material at two other manuals in a broader scale. So it can be stated that each next manual included the previous one. ${ }^{19}$

This system of relations of three parts of the whole series was broken, however, on the philosophical-theological level, where all parts were coordinated as equal elements in harmonic balance. As we can see in an illustration to Orbis pictus, Comenius understood vestibulum as a small triangular shed on two columns, a kind of a porch without steps. ${ }^{20}$ Almost exact parallel to this architectural element could be found in the Second Book of Chronicles, in the description of the First temple: 'He erected the pillars in the front of the temple, one to the south and one to the north' (Ipsas quoque columnas posuit in vestibulo templi, unam a dextris, et alteram a sinistris, 2 Chron 3:17). ${ }^{21}$ This parallel clarifies the idea of Comenius - he, obviously, wanted to compare wisdom with house, and house

19 Similar reasoning could be found in many contemporary studies.

20 Such an engraving is reproduced in many modern editions including volume 17 of DJAK (published in 1970 under supervision of Jaromír Červenka). Headpieces in other publications of works by Comenius were in the shape of a vaulted arch on two columns.

21 Compare: 'He erected the pillars at the portico of the temple' (Et statuit duas columnas in porticu templi, 1 Kings 7:21). In the Vulgate, in the First Book of Kings, as we see, there is a word 'portico', which corresponds exactly to the engraving in Orbis pictus. 
with temple. Such image of Wisdom was introduced by Solomon, who also built the First Temple. To enter the sacred place, a visitor had to pass a portico before the entrance. Then, there was a door (janua), opened thanks to the efforts of Comenius. Let us put a special attention at the complete title of the second part of the trilogy - the Unlocked Door to Languages (Janua linguarum reserata); and this title should be explained in the following way: earlier, the door to something important, sacred (Thesaurus /?/, wedding feast /?/, see below) was locked (sera means 'bar lock'), now, it is unlocked, but not opened yet, a pupil can enter. (See another interpretation of the title - as an antithesis to the manual by William Bathe - in the beginning of this paper).

It is clear, that the title of the second part of the trilogy was directly connected with religious and mystical intentions of the author. As it was with Vestibilum, the title the Unlocked Door to Languages was, obviously, associated with an image of the door opened for righteous people and closed for sinful ones - the door controlled by Jesus Christ Himself. ${ }^{22}$ The fable of Wise and Foolish Virgins in the Gospel of St Matthew ${ }^{23}$ tells us that the first ones were met by Christ at the wedding feast, and the second ones were not able to do it - the door has been closed by their arrival, and the bridegroom said them: 'Truly I tell you, I don't know you' (Mth 25:12). One of the verses in the Vulgate is quite aphoristic: et quae paratae erant, intraverunt cum eo ad nuptias, et clausa est janua ('The virgins who were ready went in with him to the wedding banquet. And the door was shut', Mth 25:10). The title chosen by Comenius Janua reserata (Unlocked Door) sounds as a reply to that aphorism: earlier, the door to something important, and necessary, and sacred was locked, and now it is unlocked, so, you should enter as soon as possible. In the last chapter of the Antechamber (under the title Conclusio), as well as in the beginning, he calls for pupils with stimulating words: 'Reader, make a rest! You will receive everything else in a proper order, when you come in this door' (Acquiesce lector! Reliqua reperies ordine ingressus Januam). The word 'Door', as the word 'Wisdom' in the first part of the manual, was written with a capital letter, connecting the first and the second parts of the trilogy on a symbolic level.

The very sense of the title Door to Languages, designed by the author, is in a specific method of learning any language, not only Latin; it is manifested in the plural form in the title: linguarum - 'to languages' (and it is certainly not pluralis poeticus). It can be proved also with multi-language publications of Vestibulum (a kind of an appendix to Janua, as we know), where a column of the Latin original text of the manual was printed in parallel with other columns - its translations into other languages: for instance, Greek, German, and Hungarian. ${ }^{24}$ Thus, Latin became a door to other languages. But the universal character of the book composed by Comenius was not only in this aspect.

22 Christ Himself is a door (He says: 'I am the door of the sheep', John, 10:7), and so is he called by Comenius in the Praefatio to Vestibulum: Faxit autem Deus, ne a Coeli Januâ, Christo, aberremus, qvicunque Coelo natos Dei filiolos erudiendos suscipimus (DJAK, 15/I, p. 309). Here we have both 'the door to heaven' and 'children of heaven' in parallel, and, we would suppose, it is not a pun.

23 As it was said before, the biblical topic of wisdom was being always actual in the pedagogic discourse of the seventeenth century.

24 Compare note 10. We do not still possess a correct and full list of those publications: Steiner (1987: p. 200). 
At the same time, and in parallel with learning language, boys made acquaintance with other subjects and phenomena of life, that is why sentences selected for the manual described the world from various sides. So, in the Antechamber, they read about physical properties of objects, their sizes, colours, taste, and aroma, about habits and features of animals and plants, about human appearance, body, health, illnesses, character, mentality, will, positive and negative emotions. Translated into any other language, such manual would become a short handbook on the environment for children, as well as a language manual. Language study is combined with the study of created world, res are mirrored in verba (similar ideas to be found in: Steiner 2007: p. 177), and one should make his way to things by studying and understanding of words (compare Vestibuli linguarum Auctarium of Comenius from the year of 1657, where important words present important things in alphabetical order).

But such conception had its weak points; first of all, in the method of teaching Latin. The author wrote in the introduction to his textbook, that he had selected about a thousand of the most commonly used words for Vestibulum: Selegi vocabula usitatiora supra mille: et redegi in sententiolas brevissimas, plerasque duarum dictionum. ${ }^{25}$ It seems puzzling. Were the verbs defining the sounds of animals really in common use in Latin? The same question can be asked concerning the beginning of Orbis pictus. If such words as 'caw' (cornicari), 'bleat' (balare), 'growl' (ringi), and 'howl' (ululare) were practical in the native language of pupils (mainly, it was German for the pupils of Comenius, as in his Praefatio he gives examples in German: kompt her, kinder; im Fruhling), they were hardly important for learning Latin. The same could be said about the terms for human organs and parts of the human body, such as 'liver' (hepar), 'lung' (pulmo), 'brain' (cerebrum), 'thumb' (pol$l e x)$, and others. Those mentioned hardly were among a thousand of the most commonly used Latin words, even if we do not speak about Classical Latin, but about that form of Latin which was used by educated Europeans of the seventeenth century. We could add such examples as 'complainant' (actor), 'defendant' (advocatus), 'furrier' (pellio), 'sponge' (spongia), 'steam pipeline' (in a bathhouse - vaporarium, hypocaustum), 'scrap of cloth' (cento), 'spurs' (calcaria), and 'bellows' (follis). We might add much more. ${ }^{26}$

Let us suppose, that the title Door to Languages has an additional meaning. In Greek and Latin traditions, as well as in Russian one, the word 'language' has not only the

25 Compare his assertions in Novissima lingvarum methodus, where (when describing the necessity of changes in the second version of Vestibulum) he says: In prima Vestibuli editione (anno 1632) selegeramus totius lingvae vocabula faciliora, quorum tironibus praesens mox usus esse possit circa illa potissimùm, quae in schola vident, audiunt, agunt. Visique sumus non irrationabiliter egisse progrediendo à facilioribus ad difficiliora, à propioribus ad remotiora (DJAK, 15/II, p. 241). It seems, as if the author thought simple matters which we would call complicated nowadays.

26 Some contemporaries of Comenius went even further, multiplicating rare words in their textbooks. In diverse variations of Janua, for instance, birds, plants and stars were growing in number. As M. Steiner notes, 'A trait shared by these editions is the multiplication of words which was, in most cases, at odds with Comenius' original desire to make the text simple and accessible to students at the level of language teaching in question, that is to say for beginners. The various editions also differed in the extent of the modifications they contained and the regions where they were published. They also contained different combinations of translations into other European languages'. (Steiner 2007: p. 180). 
meaning 'natural language', but also another one: 'people, tribe'. ${ }^{27}$ In the Vulgate, for instance, there is a phrase: A flagello linguae absconderis, et non timebis calamitatem cum venerit ('You will be protected from the lash of the tongue, and need not fear when destruction comes', Job 5:21). It is clear, that in this case the word lingua means a hostile people attacking the native people and devastating its lands, i.e. the word is used in its second meaning. ${ }^{28}$ In this context, if we admit a similar meaning in the text by Comenius, his book would be not only 'a door to all languages', but 'a door for all peoples' as well; $;^{29}$ it corresponds to the universalist trends and goals at the education of those times. The idea of 'uniting peoples' was an important part of social philosophy of Comenius; nothing could prevent inserting such sense into the text. If we accept such hypothesis, the second element of the title can get a new meaning: 'unlocked door' for peoples, for 'pagans', in accordance with a famous biblical citation, often used in medieval written tradition and interpreted in a mystical sense: 'On arriving there, they gathered the church together and reported all that God had done through them and how he had opened a door of faith to the Gentiles' (Cum autem venissent, et congregassent ecclesiam, retulerunt quanta fecisset Deus cum illis, et quia aperuisset gentibus ostium fidei, Acts 14:26).

\section{Bibliography}

AJAK - Archiv pro bádáni o životě a díle J. A. Komenského.

Caravolas, J.-A. (1993). Comenius (Komenský) and the Theory of Language Teaching. Acta Comeniana, 10(34), 141-162.

Comenius, J. A. (1636). Januae Lingvarum Reseratae Aureae Vestibulum, Quo primus ad Latinam aditus Tirunculis paratur: Cum versione interlineari Germanica. Editum à Johan-Amoso Comenio. Nunc verò ipsius Autoris Consensu Revisum multisque in locis auctum. Cum Privilegiô Sac. Caes. Majest. Et Sereniss. Elect. Saxon. Lipsiae: Sumptibus Gotofredi Grosii Bibliopolae.

Comenius, J. A. (1641). Janua linguarum Reserata: ... unà cum Januae Latinitatis Vestibulo. Authore Cl. Viro J. A. Comenio. The Entry - Door of Languages Unlocked ... together with a Portall to the Janua. Formerly translated by Th. Horn: now reviewed and enlarged both in the Latin and English, By Joh. Robotham. The fifth Edition. London, Printed by R. Young, and are sold by T. Slater, at the Swan in Duck-Lane. London: R. Young.

Comenius, J. A. (1657). J. A. Comenii Opera Didactica Omnia. Variis hucusque occasionibus scripta, diversisque locis edita: nunc autem non tantum in unum, ut simul sint, collecta, sed E ultimo conatu in Systema unum mechanice constructum, redacta. Amsterdami, ... excuderunt Christophorus Cunradus, $\mathcal{E}^{\circ}$ Gabriel à Roy. Amsterdam: Impensis D. Laurentii de Geer.

27 Russian word язычники (yazychniki, gentiles) and an idiomatic phrase nритиа во языиех (pritcha vo yazyt$s e k h$, a popular proverb) were produced from the word язык (yazyk, language).

28 For the general introduction into the language of Vulgate Bible and changes in the meaning of the substantives see classical manual: Plater \& White (1926).

29 In this context, we should note that John Amos Comenius is often called 'a teacher of peoples' in historiography. 
Corcoran, T. (1872). Studies in the history of classical teaching, Irish and continental, 1500-1700. London: Longmans Green and Co.

Čapková, D. (1987). Myslitelsko-vychovatelský odkaz Jana Amose Komenského. Praha: Academia.

Červenka, J. (Ed.). (1959). Johannis A. Comenii Janua linguarum reserata. Editio synoptica et critica quinque authenticos textus Latinos necnon Janualem Comenii textum Bohemicum continens. Praecedit commentatio de Comenii Janua linguarum reserata. Praha: Státní pedagogické nakladatelství.

Čuma, A. (1961). K voprosu o suščestvovanii russkogo pečatnogo izdanija "Preddverija" Komenskogo. AJAK, 20, 169-188.

DJAK - Johannis Amos Comenii Opera Omnia / Dílo Jana Amose Komenského. Praha: Academia.

Mištinová, A. (2000). The Janua lingvarum reserata of Jan Amos Comenius and the Ianua linguarum of William Bathe. Acta Comeniana, 14(38), 53-84.

Nicole, P. (1671). Traitté de l'Éducation d'un Prince. Paris: Charles Savreux.

Ó Mathúna, S. P. (1986). William Bathe, S. J., 1564-1614, a pioneer in linguistics (Amsterdam studies in the theory and history of linguistic science, Series 3, Studies in the history of the language sciences; Vol. 37). Amsterdam: Benjamins.

Plater, W. E., \& White, H. J. (1926). A grammar of the Vulgate: being an introduction to the study of the latinity of the Vulgate Bible. Oxford: Clarendon Press.

Steiner, M. (1987). Ein unbekanntes Vestibulum aus dem Jahre 1641. Acta Comeniana, 7(31), 193-200.

Steiner, M. (2007). Janua lingvarum: Changes and Development of a Textbook. Acta Comeniana, 20-21(44-45), 177-182.

Walde, A., \& Hofmann, J. (1954). Lateinisches etymologisches Wörterbuch (Bd. 2: M-Z; 3., neubearb. Aufl.). Heidelberg: Winter.

Irina L. Guseva, Associate Professor, PhD. / ilguseva@mephi.ru

National Research Nuclear University MEPhl (Moscow Engineering Physics Institute)

Kashirskoe shosse 31, 115409 Moscow, Russia

Vladimir V. Rybakov, Researcher, PhD. / rybakov@instrao.ru

History of Education Department

Institute for Strategy of Education Development of the Russian Academy of Education

Makarenko Street 5/16, 105062 Moscow, Russia 
